\title{
Teaching NeuroImages: Magnetic resonance perfusion and diffusion findings in hemiplegic migraine
}

Alison Ilana Thaler, MD, Brian D. Kim, MD, and Michael G. Fara, MD, PhD

Neurology ${ }^{\circledR}$ 2020;95:554-555. doi:10.1212/WNL.0000000000010249

Figure Magnetic resonance (MR) perfusion, diffusion, and apparent diffusion coefficient sequences

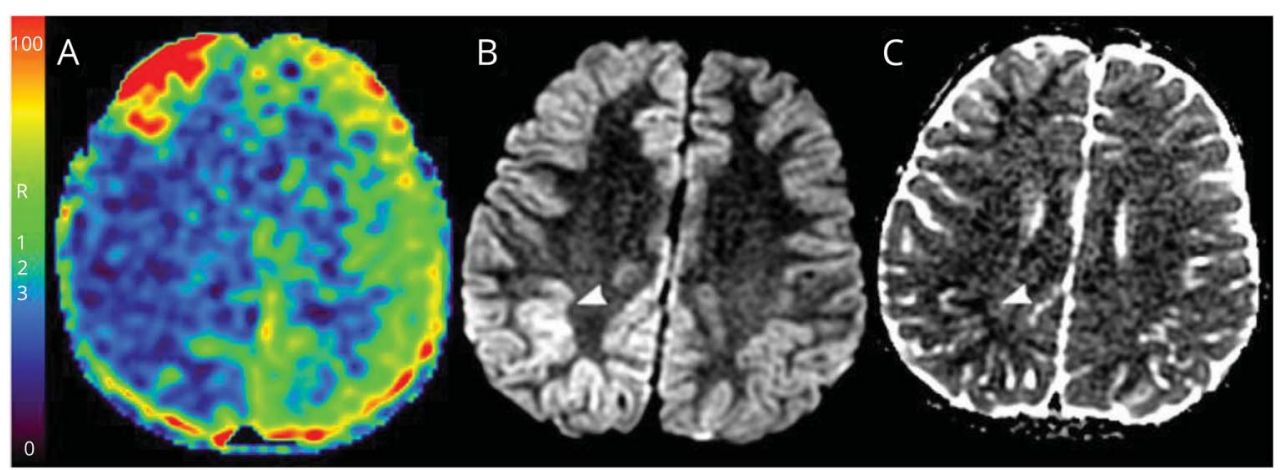

(A) MR perfusion shows decreased cerebral blood flow involving the entire right hemisphere. Cortical spreading depression is thought to be the pathophysiologic basis. (B) Diffusion-weighted MRI shows restriction involving the right parietal cortex, suggesting some degree of ischemia. (C) Associated apparent diffusion coefficient MRI shows dropout changes correlating with restriction.

A 6-year-old boy presented with acute onset of left-sided weakness and homonymous hemianopia in the setting of 3 days of severe, unilateral, pulsating headache. MRI 3 hours after symptom onset showed hypoperfusion of the entire right hemisphere, with foci of diffusion restriction predominantly involving the right parietal lobe with apparent diffusion coefficient correlate (figure). He gradually improved and was discharged with no neurologic deficits. He was discovered to have a strong family history of hemiplegic migraine.

Cerebral hypoperfusion is a relatively well-established finding in hemiplegic migraine, ${ }^{1,2}$ but associated diffusion-weighted imaging changes are rare, with only a handful of cases reported in the literature.

\section{Study funding}

No targeted funding reported.

\section{Disclosure}

The authors report no disclosures relevant to the manuscript. Go to Neurology.org/ $\mathrm{N}$ for full disclosures.

\section{Correspondence}

Dr. Thaler

alison.thaler@

nyulangone.org

\section{MORE ONLINE}

$\rightarrow$ Teaching slides

links.lww.com/WNL/

B163 
Appendix Authors

\begin{tabular}{|c|c|c|}
\hline Name & Location & Contribution \\
\hline $\begin{array}{l}\text { Alison } \\
\text { Ilana } \\
\text { Thaler, MD }\end{array}$ & $\begin{array}{l}\text { Icahn School of Medicine at } \\
\text { Mount Sinai, New York, NY }\end{array}$ & $\begin{array}{l}\text { Manuscript drafting and } \\
\text { preparation, image } \\
\text { acquisition }\end{array}$ \\
\hline $\begin{array}{l}\text { Brian D. } \\
\text { Kim, MD }\end{array}$ & $\begin{array}{l}\text { Icahn School of Medicine at } \\
\text { Mount Sinai, New York, NY }\end{array}$ & $\begin{array}{l}\text { Image acquisition and } \\
\text { manuscript revision }\end{array}$ \\
\hline $\begin{array}{l}\text { Michael G. } \\
\text { Fara, MD }\end{array}$ & $\begin{array}{l}\text { Icahn School of Medicine at } \\
\text { Mount Sinai, New York, NY }\end{array}$ & Manuscript revision \\
\hline
\end{tabular}

\section{References}

1. Lehman LL, Danehy AR, Trenor CC, et al. Transient focal neurologic symptoms correspond to regional cerebral hypoperfusion by MRI: a stroke mimic in children. AJNR Am J Neuroradiol 2017;38:2199-2202.

2. Boulouis GE, Shotar E, Dangouloff-Ros V, et al. Magnetic resonance imaging arterialspin-labelling perfusion alterations in childhood migraine with atypical aura: a casecontrol study. Dev Med Child Neurol 2016;58:965-969.

\section{Disputes \& Debates: Rapid online correspondence}

The editors encourage comments on recent articles through Disputes \& Debates:

Access an article at Neurology.org/N and click on "MAKE COMMENT" beneath the article header. Responses will be posted as rapidly as possible.

Before submitting a comment to Disputes \& Debates, remember the following:

- Disputes \& Debates is restricted to comments about articles published in Neurology within the last 8 weeks

- Read previously posted comments; redundant comments will not be posted

- Your submission must be 200 words or less and have a maximum of 5 references; the first reference must be the article on which you are commenting

- You can include a maximum of 5 authors (including yourself)

\section{Sign Up for the AAN's Axon Registry}

The AAN encourages its US members to show their interest in participating in the Axon Registry。 by signing up today.

Use the Axon Registry to:

- Simplify reporting requirements under MACRA's Quality Payment Program and avoid penalties while reducing your administrative burden

- Meet your MOC Part IV requirements and waive up to eight credits of Part II Self-Assessment

- Choose from 22 AAN neurology-specific quality measures that fit your practice

- Use data to understand your practice and identify where improvements can be made to patient care

- Manage your patients at a population level; look at a specific group of patients based on conditions, risk factors, demographics or outcome

- Demonstrate your value to payers when negotiating reimbursement

- Enjoy multi-year, fee-free access when you sign the agreements and integrate your EHR with the registry

Learn more at AAN.com/view/Axon and send your questions to registry@aan.com. 


\section{Neurology}

\section{Teaching NeuroImages: Magnetic resonance perfusion and diffusion findings in}

hemiplegic migraine

Alison Ilana Thaler, Brian D. Kim and Michael G. Fara

Neurology 2020;95;554-555 Published Online before print July 9, 2020

DOI 10.1212/WNL.0000000000010249

\section{This information is current as of July 9, 2020}

\section{Updated Information \& Services}

References

Subspecialty Collections

Permissions \& Licensing

Reprints including high resolution figures, can be found at: http://n.neurology.org/content/95/12/554.full

This article cites 2 articles, 1 of which you can access for free at: http://n.neurology.org/content/95/12/554.full\#ref-list-1

This article, along with others on similar topics, appears in the following collection(s):

All Cerebrovascular disease/Stroke

http://n.neurology.org/cgi/collection/all_cerebrovascular_disease_strok

DWI

http://n.neurology.org/cgi/collection/dwi

Migraine

http://n.neurology.org/cgi/collection/migraine

MRI

http://n.neurology.org/cgi/collection/mri

Information about reproducing this article in parts (figures,tables) or in its entirety can be found online at:

http://www.neurology.org/about/about_the_journal\#permissions

Information about ordering reprints can be found online:

http://n.neurology.org/subscribers/advertise

Neurology ${ }^{\circledR}$ is the official journal of the American Academy of Neurology. Published continuously since 1951, it is now a weekly with 48 issues per year. Copyright () 2020 American Academy of Neurology. All rights reserved. Print ISSN: 0028-3878. Online ISSN: 1526-632X.

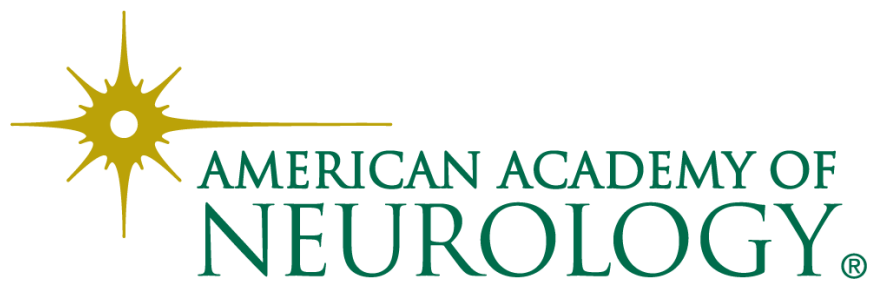

